\title{
Chapter 13 \\ Differing Romani Mobilities? The Case of Cross-Border Migration of Roma Between Slovenia and Austria
}

\author{
Julija Sardelić
}

Different public debates discuss the position of Roma in Europe as if they were one of the most mobile populations in Europe. The position of mobile Romani individuals became especially visible after the 2004 and 2007 European Union (EU) Enlargements. However, only a certain type of mobility of intra EU Romani migrants became particularly highlighted by the headlines of European Media: the one that more or less corresponded to a stereotypical image of a "Roma nomad" and depicted Roma as a potential threat to the social welfare systems of host states. This chapter argues that the reasons why Romani individuals become mobile are more complex and diverse than of those presented in the European public domain. The chapter traces life histories of Slovenian citizens who identify as Roma and have been mobile for work between Slovenia and Austria. It offers counter-narratives on how differing mobility practices of different Romani individuals are.

\subsection{Introduction}

At the beginning of April 2014, a group from the Romani civil society in Slovenia held a protest under the slogan "No Tolerance for Intolerance" to commemorate International Romani Day (8th April). In the town of Murska Sobota, the capital of the north-east region of Pomurje, and the place in Slovenia with the largest Romani population (M.R. 2017), they painted over a piece graffiti to counter its message of intolerance. The graffiti stated: "Disabled people have to work, while Roma misters are enjoying themselves." (Pojbič 2014). ${ }^{1}$ This statement conveyed a wide-spread

\footnotetext{
${ }^{1}$ All texts that were not originally in English but in Slovenian, including the interviews, were translated by the author.

J. Sardelić $(\bowtie)$

KU Leuven International and European Studies Institute (LINES), Leuven, Belgium

e-mail: julija.sardelic@kuleuven.be
} 
prejudice towards Roma: that they do not want to work, and prefer to live a life of leisure on social benefits. Commenting on the graffiti, the President of the Roma Community Council in Slovenia, Darko Rudaš, stated: "Roma would very much like to work, but they have become the greatest losers on the labour market, due to the combination of the economic crisis and prejudice towards them" (in Pojbič 2014). Rudaš added:

\begin{abstract}
In the Pomurje region, Roma cannot get any employment despite the fact they want to work. The prejudice still exists from the side of the employers. Because of that many found their employment in neighbouring Austria, where we have identified more than 500 Roma workers. Most of the work they do is heavy manual labour that Austrians decline. [...] Despite the fact they have to drive 100 kilometres just to get there, in Austria they are respected as responsible workers. (Pomurec 2014)
\end{abstract}

This chapter contextualizes the mobility practices of those Roma who are Slovenian citizens working in Austria. The image of Roma living on social benefits rather than working exists in various national contexts (Richardson 2014; Ciaian and Kancs 2016; Martin et al. 2017), although this prejudice has also expanded beyond simply national contexts. For example, it also appeared in the debates on EU citizenship and how Romani individuals practice and engage with their supranational citizenship (Parker 2012; Parker and Toke 2013; Aradau et al. 2013; Çağlar and Mehling 2013; Faure Atger 2013; Ram 2013). After the fall of the Berlin Wall and in the discussions that occurred on EU accession for the former socialist countries with high Romani populations (especially Bulgaria and Romania), the public discourse perpetuated the fear that Roma would move en masse towards "old" EU Member States (Guglielmo and Waters 2005; Sardelić 2018). This fear was not only based on that of mass migration, but also on a perception that Romani migration is particularly unwanted (Yuval Davis et al. 2017; Richardson 2014; Martin et al. 2017; Vermeersch 2013).

Neither the public discourse nor the scholarly literature have previously discussed the migration and mobility of Roma who are Slovenian citizens. While there are no official numbers of how many Slovenian citizens who identify as Roma are migrating or moving between Slovenia and Austria, the unofficial number of 500 that Rudaš put forward seems low. However, taking into account that only 3246 Slovenian citizens declared themselves as Roma in the most recent population census (Office for National Minorities 2005), this number becomes statistically higher. More importantly, with his statement Rudaš highlighted a particular form of crossborder mobility that was previously overlooked by the media and policymakers, as well as in scholarly debates.

This chapter explores who the Romani individuals are, who either commute between Slovenia and Austria, or have migrated permanently to Austria. It presents excerpts from life story interviews with Romani individuals who are or were practicing their rights as EU citizens to work in another EU Member State. The general aim of the chapter is not to point out a pattern that could be labelled as either Romani migration or mobility, but rather to show that there are alternative narratives to what is usually seen as "Romani migration" in Europe. The chapter seeks to point to differing mobility practices by Roma in the EU, which are usually not discussed in public debates and are not connected to "Romani migration". 
In the first section, the chapter highlights the representation of Romani migrants in Europe, and indicates that there is a lack of reliable statistics on how many Roma actually do migrate in the EU. ${ }^{2}$ In the second part, the chapter contextualises the migration and mobility of Roma from Slovenia within the migration history of the former Yugoslav space and the position of Roma in Slovenia. In the third part, it focuses on the narratives of individuals who offer their own perspectives on the reasons why they move between Austria and Slovenia, or why they have migrated for employment. The chapter concludes with a discussion on what new insights these narratives give on the social construct of Romani migrants and migration in Europe.

\subsection{The Representation of Romani Migrants in Europe}

In the public discourse there has been a certain representation of what Romani migration is, and of who such migrants are. Romani migrants with EU citizenship have usually been represented either as beggars (Yuval Davis et al. 2017) or "benefit tourists" (Richardson 2014; Martin et al. 2017; Sardelić 2018). However, in recent years scholarly research has shown that the migration and mobility of Roma are not as homogenous as assumed in the media discourse (Nacu 2010; Grill 2012; Vermeersch 2012; Pantea 2012; Vlase and Voicu 2013). Some studies show that differences in migration patterns do not arise simply because of ethnicity, but need to be observed from an intersectional perspective, and include the consideration of, for example, gender and class (Nacu 2010; Kóczé 2017). However, a large proportion of this research focuses on particular migration patterns of Roma, especially from countries such as Romania to countries like the UK (Matras and Leggio 2018; Humphris 2017), Spain (Magazzini and Piemontese 2016; Vrabiescu and Kalir 2017), Italy (Solimene 2011; Hepworth 2012) and France (Ram 2013; Sardelić 2017a), as well as on the construction of the representation of the poor Roma migrant (Richardson 2014; Ciaian and Kancs 2016). This image of a poor Roma migrant has been used to show the limits of EU citizenship (Parker 2012) as well as in broader debates on the politics around migration in general, such as those seen around the UK's EU membership referendum (Brexit) ${ }^{3}$ and benefit tourism by EU citizens (Sardelić 2018). As Can Yildiz and Nicholas De Genova argued, the position of Roma migrants indicates the "larger politics of mobility as a constitutive feature of the socio-political formation of the EU" (Yildiz and Genova 2017). In the debates on EU citizenship, the position of Romani migrants in particular has been presented as an indicator of the limits to the EU's free movement policies (Faure Atger 2013; Sardelić 2018).

What is more, the latest research on the discourse surrounding Romani migrants shows that they are being framed not simply as an ethnic group, but as a "racialized minority" in Europe (Yildiz and Genova 2017; Kóczé 2017; Van Baar 2017;

\footnotetext{
${ }^{2}$ For a problematisation of reliable statistics see the contribution by Vera Messing in this volume.

${ }^{3}$ See the contribution by Viktor Leggio in this volume.
} 
McGarry 2017; Sardelić 2017b). They are visible despite the fact that the available numbers (or better yet, estimates) show they are not one of the most dominant migrant groups in Europe. As Claude Cahn and Elsphet Guild stated:

Information on Romani migration has, if anything, been overproduced. The arrival of one hundred or two hundred Roma from another country can trigger front-page news coverage in the yellow press and more serious media for days. However, beyond certain particular micro-scenarios, reliable statistical data on Romani migration is largely unavailable. (Cahn and Guild 2008: 33)

While population censuses tend to underestimate the Romani population, since many Romani individuals prefer not to identify themselves as such (Bernát and Messing 2016), Cahn and Guild claim that the media has an effect of overestimating the number of Romani migrants. According to these authors, some sources estimate that there are around 30,000 Romani migrants in Germany, 80,000 in Italy, and some 20,000 in Austria, as well as 6000 Roma migrants from Romania in the UK (Cahn and Guild 2008: 33). In most of these countries, the migrants identified as Roma did not simply start coming with the 2004 and 2007 EU enlargements, but had longer migratory connections with these places, where they came as forced migrants during the Yugoslav wars (Perić and Demirovski 2000; Sigona 2003; Solimene 2011; Sardelić 2017a). Some other studies show that there is a greater number of mobile Roma between neighbouring countries. For example, informal estimates have shown around 100,000 Roma moving in different mobility patterns between Albania and Greece (Cahn and Guild 2008), but this cross-border migration between neighbouring countries has sparked little scholarly attention (Vullnetari 2012). There has also been very little quantitative research done on what are the aspirations of Romani individuals in migratory processes and what countries are the most desirable for them. A study on the emigration intentions of Roma showed that in certain contexts they give preference to those countries that are either neighbouring or closer geographically. For example, Roma with the intention to emigrate from the Czech Republic indicated Austria, Slovakia and Germany as their top destination countries, while those from Bulgaria indicated Turkey as their favoured country (Duval and Wolff 2016). On the other hand, Roma from three former Yugoslav republics, Croatia, Serbia and Macedonia, all stated that Austria was one of their top choices (ibid.). Since Serbia and Macedonia are at the present EU candidate countries, this shows that the choices of most desirable countries for emigration are not only based on the EU free movement policy, but also on particular constellations in the countries of origin and specific histories of migration (Sardelić 2017b).

\subsection{Migration Histories of Roma from the Former Yugoslav Space}

While Duval and Wolff (2016) did not include Slovenia in their studies on the emigration intentions of Roma, certain parallels can be found with other post-Yugoslav countries due to their common historical backgrounds. The Former Socialist 
Federative Republic of Yugoslavia (SFRY) was the first socialist country to sign a number of bilateral agreements with the countries from the former Western Bloc. These bilateral agreements allowed Yugoslav citizens to seek temporary employment abroad (Novinšćak 2009). SFRY had such an agreement both with Germany and Austria. For the former Yugoslavia, this arrangement was one way to address the issue of unemployment, especially in rural areas. However, as I argued in my previous work (Sardelić 2017a), it was also partially done to address the problem of unemployment among Roma who were Yugoslav citizens. There are no reliable numbers regarding how many Yugoslav Roma sought employment in Austria or Germany (Matras 2000), as at the time they were simply included in the statistics with other Yugoslav Gastarbeiters. Due to the previous migratory networks, many Romani individuals from Yugoslavia also sought asylum in Austria during the Yugoslav wars (Cahn and Guild 2008). While they were in most cases given only temporary protection status (Sardelić 2017c), it was often not clear whether Roma from conflict-ridden Kosovo and other parts of the former Yugoslavia moved to Austria and Germany as labour migrants or as forced migrants. The labour/forced migration dichotomy also constitutes the main difference in the positioning of those Roma who later became Slovenian citizens. Roma with Slovenian citizenship were not affected by the Yugoslav wars to such an extent as those from other former Yugoslav countries. They were always labour migrants and not asylum seekers. In addition, Slovenia borders Austria, and a number of Romani settlements are located in the vicinity of the Slovenian-Austrian border. This contributed to a specific form of commuting between the two countries, as I will discuss in the next sections.

\subsection{The Position of Roma in Slovenia}

To date there has not been any academic account on the mobility and migration of Roma from Slovenia. Moreover, until recently (Sardelić 2016; Szilvasi 2018) the discussion on the position of Roma in Slovenia generally did not attract a great amount of international scholarly attention. From the policy-making perspective, Slovenia was not a full participatory member of the Decade of Roma Inclusion (2005-2015), ${ }^{4}$ but rather had an observatory status, like the United States. Slovenia also positioned itself on the international stage based on the perception that it was a country that underwent a smooth post-socialist transition without any significant rise in "ethnic tensions" or hostility towards its minorities. After gaining independence, there were only a few critical accounts of how Slovenia positioned its

\footnotetext{
${ }^{4}$ The Decade of Roma Inclusion was launched in 2005 and represented the first transnational project which meant to improve the social and political conditions of the Roma. Twelve European countries (Albania, Bosnia and Herzegovina, Bulgaria, Croatia, Czech Republic, Hungary, Macedonia, Montenegro, Romania, Serbia, Slovakia, and Spain) developed a National Action Plan to improve the condition of the Roma in the Decade's priority areas of education, employment, health and housing. Slovenia and the USA were external observer (UNDP 2015).
} 
minority citizens, but, since the turn of the millennium, more analysis on this topic has emerged (Zorn 2009; Deželan 2012; Sardelić 2017a). Slovenia not only managed to escape the extensive conflicts that were seen in most other post-Yugoslav states, but also did not experience a major economic downfall in the 1990s, as suffered by other states undergoing post-socialist transitions. Some scholars argue that after its independence Slovenia developed policies that protected its minority citizens, including Romani as well as the Hungarian and Italian minorities (Klopčič 2007). Finally, one can argue that the position of Roma in Slovenia also attracted very little scholarly attention due to the fact that this population is very small compared to other post-socialist states. Therefore, their migration would not have represented such a problem with regard to the EU policy of free movement. According to the 2002 population census, just 3246 individuals declared themselves as Roma (Office for National Minorities 2005). However, even earlier unofficial estimates by different Romani activists only range between 10,000 and 50,000 individuals who could be identified as Roma (Latham 1999: 221). Most Roma in Slovenia live in two rural regions: Dolenjska, located on the Slovenian south border with Croatia, and Pomurje, which is the most eastern region in the country, bordering Austria to the north, Croatia to the south and Hungary to the east (Sardelić 2012).

Although the Romani minority in Slovenia is small, they are among those Slovenian citizens who still face major obstacles when entering the labour market. According to the National Programme of Measures for Roma 2010-2015, produced by the Government of Slovenia, 2193 Roma were registered at the Employment Office of Slovenia as unemployed, which represented $2.5 \%$ of all unemployed residents in the country (Government of the Republic of Slovenia 2010). At the same time, comparing this figure with the number of all those who identified themselves as Roma, this would indicated that $67 \%$ of this population was unemployed. Yet the question is whether this number reflects the reality, since there is are discrepancies in the various estimations. Furthermore, according to the National Programme, in 2009 a total of 890 Roma were included into the active employment policy measures. According to the National Programme, 79 Romani individuals were registered as having regular employment in Slovenia with an open-ended contract. Importantly, the National Programme did not count as employed those Romani migrants who were working outside Slovenia.

\subsection{Contextualizing Economic Migration of Roma from the Pomurje Region}

As part of my PhD studies, I conducted fieldwork in several Roma communities in the region of Pomurje in 2012. During this fieldwork, I conducted 20 in-depth semistructured interviews with individuals who identified themselves as Roma. In addition, I also performed participant observation and many informal conversations with various members of these selected communities. In October 2017, I conducted 
another series of interviews, in the form of life stories, with those individuals who I had previously identified during my fieldwork as having experience of being employed in Austria. These life stories are particularly focused on the employment histories of four individuals. At that time, Maria was working as a deputy manager of a section in a grocery shop; Tania was working as an integration officer for EU citizens (mostly Roma), and as a teacher of German as a second language; Kiki used to work in the factory dealing with leather materials for luxury cars in Austria, but since then moved to Berlin; finally, Andi occasionally worked in Austria doing seasonal work on different farms. In this section I will present their views on why they found employment in Austria, and why many Roma from Slovenia decide to seek employment in this neighbouring country.

All interviews were conducted in Slovenian: this was either the mother tongue of the interviewees or they had a knowledge of it on the level of a native speaker, while most of them were also fluent in German. Since some of the issues discussed could be considered ethically sensitive, and Romani settlements in Slovenia are relatively small (with an average of 200 inhabitants in each), in order to preserve the anonymity of the interviewees, I decided not only to use pseudonyms, but also not to name the Roma settlements from which these individuals came from, although all are located in the Pomurje region. According to the 2002 population census and other unofficial estimates by different civil society organizations, Roma account for up to $10 \%$ of the population in Pomurje (Klopčič 2007), which is considered to be Slovenia's poorest and most rural region. The region was severely hit by the last financial crisis, since many large textile factories, which by means of state aid had survived the post-socialist transition, collapsed after 2008. These collapses happened when the government decided not to continue giving subsidies to the local factories, which in their best years, during the socialist period, employed up to several thousand people (Fink Hafner 2010: 1165).

The greatest number of Romani settlements in this region are located in the vicinity of the Austrian border, while some are close to the Croatian border or in the proximity of the Hungarian border. These settlements were mainly established as permanent living spaces in the years after WWII and up to the 1970s, when a state decree was issued stipulating that all Romani children should also be included in the education system (Sardelić 2012). In the fieldwork conducted in 2012, I carried out my research in two settlements located near the Austrian and Croatian borders. Very early in my work it became clear to me that the settlement near the Austrian border did not fit the stereotypical image of a Roma settlement, and did not distinguish itself from other villages populated by the majority population. In the Romani communities near the Austrian border, where I also conducted my research, the data collected demonstrated that the unemployment rate among its inhabitants was not significantly higher in comparison to that seen among the majority population in the region, and remained similar even with the emergence of the economic crisis. Yet as Rudaš stated (Pomurec 2014), this was not because these individuals were able to find employment in Slovenia, but precisely because of their proximity to Austria.

The Roma settlements in Slovenia near the Austrian border, where I conducted my research, were considered by media and public authorities to be an example of 
"best practice" when it comes to Romani integration in Slovenia (see Institute for Ethnic Studies 2004). As described in the previous paragraph, unemployment did not pose a major challenge in these settlements, even after the onset of the economic crisis, as also noted by the interviewees. Still, this portrayal is somewhat paradoxical. This is because the success of these Roma settlements and their residents cannot be attributed to the full inclusion in the labour market in Slovenia, since most of the inhabitants found official gainful employment in the neighbouring state of Austria.

Romani individuals are not the only Slovenian citizens who sought employment in Austria. According to different sources there are approximately 20,000 Slovenian citizens who work in Austria and commute on a daily basis (Reporter 2017). However, according to the opinion of most interviewees, most Slovenian citizens who are Roma and employed find work in the neighbouring state.

\subsection{Romani Individuals as Economic Migrants: Life Stories Between Slovenia and Austria}

One of the first things I discussed with Maria (a woman in her early 30s, originally from a Roma settlement near the Austrian border), was her employment status, when she was still in Slovenia. She stated that the employment she had in Slovenia was based on projects to improve the position of Roma, usually funded by the EU:

When I was working in Slovenia, I was at first working on a project, and then the project was over, I got a job on another project in Pomurje. But there were some complications there, I did not get regular payment. And then I was unemployed for some time. [...] But I am now so old that I did not want to be dependent on my parents. I decided to go to Austria.

Tania, a woman in her early 30s with a master's degree who was the president of a Romani NGO in Slovenia, also migrated permanently to Austria. Similar to Maria, she felt that in Slovenia she could only get so-called "project work":

I had a feeling it will be very difficult for me to get employment. I thought that if I get employment there, I would only be able to work on projects. This would be employment only for couple of years. And then nothing. In Austria, I saw there are better possibilities, but also there were personal reasons why I decided to go to Austria.

I asked the interviewees what they saw as the reasons why Roma are looking employment in Austria. Maria responded that the region of Pomurje is already disadvantaged and there is a lack of jobs, especially for Roma. Local employers were usually non-Roma Slovenians, and would also prefer to employ other non-Roma Slovenians:

Pomurje is so small that everybody knows you. This should not have an effect, but it does, because everyone knows you. But there is really a big problem with unemployment there, not only among Roma. And employers would rather give employment to someone else [to a non-Roma Slovenian] and not to me. 
However, Andi, a man in his early 30s from a different Roma settlement, proposed that this does not only happen in Pomurje. After finishing high-school, he was working in the army, which later on cut the number of employees. After he lost his job, he worked in different short-term jobs with longer periods of being unemployed, and he then decided to start doing seasonal jobs in Austria. He claimed that one of the main reasons for his seeking employment in Austria was not just that the region where he came from was disadvantaged, but also the general prejudice towards Roma, which is found in other parts of Slovenia too:

Pomurje is an economically disadvantaged region, but I also went to Maribor, I also had job interviews in Celje, in Novo mesto and Velenje, and it was the same. When they see you, they say they have other candidates. One even told me that he had a bad experience with Roma, and while he believes me that I am hard working he still said no.

Tania stated that she had a similar experience with the employment services in Slovenia:

In my opinion, there are not many jobs available. But this is not the main reason. I think it is still true that no matter if you have education they would rather take someone else, not Roma. The only exception is if the job requires knowledge of the Romani language or is in any way connected to Roma. I still remember when I was at the Employment Office, the employment advisor there was shocked that I wanted to write in my employment profile that I can speak Romani. She told me between the lines that she was afraid this would be a reason why I would not get a job. This was shocking for me.

Kiki, a man in his early 50s who had completed vocational training, said that the reason why many people decide to migrate to Austria was for the better salaries:

The salaries are better. When I was working there, I had 1,200 euros. When I worked two Saturdays, I got to 1,400 euros. That was my salary. That was my net salary.

Tania stated that it is not only the better pay, but also the social welfare system that attracts many people to decide to work in Austria. Also, similar to most of the interviewees, Tania said that Austrians do not see Roma as unwanted Romani migrants, but simply as foreigners:

It is because of the better structured social welfare system. All the Roma employed in Austria, their children also get social benefits. [...] Also a higher salary. And there is very little discrimination on the basis that they are Roma. They are seen as foreigners who work in Austria.

In another interview, Kiki explained his employment history and stated that although he has worked in construction for over a decade there was a lack of genuine opportunities for progressing in his career in Slovenia, or getting a better salary:

You know how it is in Slovenia, everything is falling apart, and there is no employment. [...] When I was doing my truck driving license exam, then this [employee at the employment centre], she said that: "You know mister, you chose a difficult profession". And I asked her why. She said driving trucks is difficult. And I asked her: "So should I work with a shovel my entire life?". [...] I was working in construction for 11 years in Slovenia, regularly. But then I started working with metal [picking and selling scrap metal]. But then the employment centre gave this opportunity if you wanted to get into another profession, and then I wanted to become a truck driver, and I passed all my exams on the first try. Then I 
was sent to Maribor for a specialized health exam. And they found out that I have colour blindness. And then I said to the doctor: "Look, when I went to the army they said that I am able to go, but I already had colour blindness then". I was in the army for 150 days. I had a feeling that this doctor did not want me to progress.

I asked Tania when was it that more Romani individuals with Slovenian citizenship started working in Austria. She stated that it was when Slovenia joined the EU, but even more so with the economic crisis in 2008, when jobs in Pomurje became even more difficult to come by. However, her reply was twofold and conveyed a complex reality: while the younger generation from her Romani settlement started migrating for work after the economic crisis, there was already a tradition of working abroad from when Slovenia was still a part of socialist Yugoslavia:

From my former settlement, out of those who have employment, 80 per cent of them work in Austria. I do not know when this trend started. I think it was with the European Union, when Slovenians started working abroad more, Roma also started. Also with the economic crisis. Because there are very few jobs in Pomurje, but also now in Slovenia. [...] Before Slovenian independence not all the settlements had people who were working abroad, but this depended on the tradition of each settlement. Our settlement always had this tradition. Already our ancestors worked abroad, they were in Germany, Australia, in Austria. This tradition was alive, there were also some working in Libya. [...] In some other settlements, they were, for example, selling goods on the market.

Tania highlighted the fact that the trend of working abroad was already a reality for many Roma during the period of Socialist Yugoslavia. Romani individuals did not only work in Austria and Germany, but also in places like Libya, which was possible because of Yugoslavia being a part of the Non-Aligned Movement. Tania's statements show that the migration and mobility of Romani individuals have to be put in a broader context in order to be understood. Similar conclusions can be drawn on the basis of Kiki's interview. First, he stated that fewer Roma worked abroad in Yugoslavia, because they were able to get work in the country:

They were working before in big companies, construction sites, then the textile industry. Half of [name of a Roma settlement] was working in places like that. More than half. And then this water company, Mura. Even my father was working there. In the time of Yugoslavia it was not a problem if you did not have school. You got a shovel.

Later in the interview, Kiki stated that there was particular turning point when more Romani individuals started working in Austria. With the European Union the border not only opened up for Slovenian citizens, but also for EU citizens. When Slovenia joined the Union, Kiki was working informally collecting scrap metal. His story showed that collecting scrap metal is not something that would intrinsically part of Roma culture, but it was a more profitable business for him personally at the time. This then became less profitable when Slovenia joined the EU, because besides the formal market the informal one became more accessible to other EU citizens too. With this shift, EU citizens from Hungary also started collecting scrap metal from Slovenia (Kiki did not specify whether it was only Roma or also non-Roma Hungarians who did this):

So I quit the formal labour market and started doing scrap metal, but then when the Hungarians came, when the border opened, we saw that doing metal did not bring such a profit. 
The stories of Romani individuals, such as those of Maria, Tania, Andi and Kiki, remain invisible in the wider media. On the basis of their examples, it seems that Roma are racialized as a minority only when they fit a certain pattern of migration, externally ascribed as "Romani migration", which is seen as a part of "their culture". Tania now lives in Austria, and she works on the integration of EU citizens from other Member States. She claimed that there is a very small proportion of Romani migrants who are begging on the streets:

I work on the integration of EU immigrants, those who are mostly Roma. The data we have there shows that a very small number of those are begging on the streets. But even those who are on the streets, they are selling newspapers. Many work in different sectors. [...] From my own experience I can say that Roma also work in restaurants, hotels, in grocery shops, logistics, not only as low-skilled workers, but also on better positions as managers. Also in health institutions.

In their life stories all the interviewees claimed that their position as workers in Austria was better than in Slovenia. Maria felt that there were many more opportunities for advancing in her career, and that there was more job security:

There I got employment right away, on the second day I was in Austria. For the first three months I was working in a restaurant. And then I decided to stop working there and I found another job in a grocery store where I still work today. After nine months I got a promotion. Now I have regular employment, not connected to any projects, a permanent contract.

Similarly, Andi felt that Roma were seen as better workers in Austria than in Slovenia:

I did seasonal work in Austria. We were picking grapes and then horseradish, everything that needed to be done on the farm. [...] Only Roma work there. [...] The bosses there mostly take Roma, because they are fast and good workers. [...] Some are there during the week, those who live far away, some drive there. [...] They are not looking at you as Roma, for them it is only important that you show you are good at your work. Only this is important.

However, Andi also noted that they worked for lower salaries than Austrian citizens:

In the leather factory, in the slaughter house, 90 percent are Roma. For Austrians, these are not well-paid jobs. By Austrian standards 1400 euros is not a lot. For Slovenians this is good.

Kiki worked in the leather factory for 5 years. While he said the salary was good, he also said that Austrians would not work in such working conditions. This was not only because of the long drive to work, but also because of the dangerous chemicals used in the factory, and the initial lack of certainty as to whether they would be paid:

But then my brother-in-law got me to Austria. He said this is a Leitfirma [start-up company], and I got scared a bit, because you know how it is with Leitfirma. You can get money or you don't get money. And I was thinking, I will be driving so far, but then not get payment. And then my brother-in-law said, no, no, you come, I am already working there three months. But then I saw that the payment is good, 1,200 euros. So first I worked in a Leitfirma for one year, and then regularly for four years. Although I was working in Austria, I did not know how to speak German, because there were a lot of Roma there. Also Hungarians were working there and speaking their own language. There were also Hungarian Roma. A lot of 
Roma work there. [...]. I had an easy job, but it was difficult because of the driving. The drive to work destroyed you already. [...] A smart Austrian would not work there, because they know what it means. There are chemicals there. It is difficult work.

Later on, Kiki moved to Germany, because of a new relationship:

So my partner did not want to leave Berlin because of her son. And then I said I decided, if you could find me work in Berlin, then no problem. It does not matter what kind of work.

You know, we are universal, we do everything.

The negative attitudes towards Roma in Slovenia can be confirmed by research studies on social distance, which show that the majority population expresses the largest social distance towards Romani (Klopčič 2007: 33). However, as statistics shows, on the one hand this attitude did not particularly change with the growing economic crisis nor the $2004 \mathrm{EU}$ enlargement. On the other hand, there were some other events that significantly changed the position of Roma working on the Austrian labour market. In 2014 the Constitutional Court of Slovenia ruled that all daily temporary migrant workers in Austria, including Roma, would have to pay additional tax (corresponding to the difference between the Slovenian and Austrian levels of taxation, since the latter is lower on salaries), in order to be taxed equally to Slovenian citizens employed in their home country (Sobotainfo 2014). However, due to the progressive taxation scale in Slovenia, this meant that temporary migrant workers in Austria were then taxed at a higher rate than those doing the same work in Slovenia. When I asked my respondents how this affected them, many of them stated that they had already permanently migrated to Austria, closer to their place of work, while most of who had not were thinking about leaving Slovenia because of this change in taxation. Both Tania and Maria claimed there is a trend, particularly among younger Romani individuals, of moving to Austria permanently:

As far as I know most of them [the older Roma] are still driving to work. But the younger generation are deciding to migrate.

Tania claimed that this is not only a trend among Roma, but also among those who identify as Slovenians:

Many, not only Roma but also [non-Roma] Slovenians, moved to Austria because of the new law. Many Slovenians move there and spend the money on themselves rather than giving it back to the state.

\subsection{Conclusion}

In this chapter I contextualised the position of Roma who are Slovenian citizens, but I chose to migrate to the neighbouring country of Austria for work. I presented excerpts of Romani individuals' life stories who found themselves in such a position. The aim of this chapter was not to present certain trends in what is usually considered as "Romani migration", but rather to show, as Peter Vermeersch (2018) stated, that the notion of Romani migration becomes problematic, once alternative 
narratives on why and how Romani individuals migrate are presented. While it is impossible to draw any general conclusions based on these qualitative approaches, generalisations based on numbers of Roma and of Roma migrants living in each EU Member State are also very questionable, since these numbers are usually only estimates. However, Roma are still very visible as migrants in the EU, therefore it is important to present narratives which do not fit the media representation and image of Roma as a racialized minority.

While in comparison with the entire population of Slovenia the number of temporary migrant workers in Austria is not high, it is, according to my respondents, very high among the individuals belonging to Romani minorities, especially those living in settlements next to the Austrian border. According to their interviews, it was a lot easier for them to find employment in Austria, because they were not regarded as Roma but included in the group of other temporary migrant workers. However, the interviewees did not claim that Austria is a sort of paradise for Roma from Slovenia, but instead noted the inefficient polices that were developed in their own country for their integration, while also making some criticism of Austria (such as lower wages for foreign workers, and dangerous working conditions).

It might be argued that both Slovenian policies for the improvement of the position of Roma, as well as the Austrian policies aimed at the inclusion of workers from abroad, had unpredictable consequences. For example, as some of the respondents argued, they were only able to get "project work" in Slovenia, being employed on projects that were mostly aimed at improving the position of Roma. However, these projects did not offer any structural or longer-term employment, and in some cases were even used as an excuse by potential employers as to why they were not employed in more stable work in Slovenia.

In conclusion, what this chapter shows through the life stories of Romani individuals from Slovenia who work in Austria is that migration - both on a daily basis as well as permanent - is not in any way intrinsic to the Romani population and its culture. It is rather the active response of Romani citizens to different societal challenges, which might not have to do solely or mainly with direct discrimination, but depend instead on more structural accounts of inequalities, in which Roma find themselves having to navigate their mobility and employment choices.

\section{Bibliography}

Aradau, C., Huysmans, J., \& Macioti, P. (2013). Mobility interrogating free movement: Roma acts of European citizenship. In E. Isin \& M. Saward (Eds.), Enacting European citizenship (pp. 132-154). Cambridge: Cambridge University Press.

Bernát, A., \& Messing, V. (2016). Methodological and data infrastructure report on Roma population in the EU (Milestone 8.5). Leuven: InGRID project. Retreived June 2, 2017, from http:// inclusivegrowth.be/project-output.

Çağlar, A., \& Mehling, S. (2013). Sites and scales of law: Third country nationals and EU Roma citizens. In E. Isin \& M. Saward (Eds.), Enacting European citizenship (pp. 155-177). Cambridge: Cambridge University Press. 
Cahn, C., \& Guild, E. (2008). Recent migration of Roma in Europe. Retrieved June 2, 2017, from http://www.osce.org/hcnm/78034?download=true

Ciaian, P., \& Kancs, A. (2016). Causes of the social and economic marginalization: The role of social mobility barriers for Roma. Retreived June 2, 2017, from http://publications.jrc. ec.europa.eu/repository/bitstream/JRC100798/lfna27794enn.pdf

Deželan, T. (2012). In the name of the nation or/and Europe? Determinants of the Slovenian citizenship regime. Citizenship Studies, 16(3-4), 413-429.

Duval, L., \& Wolff, F. (2016). Emigration intentions of Roma: Evidence from Central and SouthEast Europe. Post-Communist Economies, 28(1), 87-107.

Faure Atger, A. (2013). European citizenship revealed: Sites, actors and Roma access to justice in the EU. In E. Isin \& M. Saward (Eds.), Enacting European citizenship (pp. 178-193). Cambridge: Cambridge University Press.

Fink-Hafner, D. (2010). Slovenia. European Journal of Political Research, 49(7-8), 1163-1172.

Government of the Republic of Slovenia. (2010). National programme of measures for Roma of the government of the Republic of Slovenia for the period 2010-2015. Available at: http:// ec.europa.eu/justice/discrimination/files/roma_slovenia_strategy_en.pdf. Accessed 6 Nov 2017.

Grill, J. (2012). 'Going up to England': Exploring mobilities among Roma from Eastern Slovakia. Journal of Ethnic and Migration Studies, 38(8), 1269-1287.

Guglielmo, R., \& Waters, T. (2005). Migrating towards minority status: Shifting European policy towards Roma. JCMS: Journal of Common Market Studies, 43(4), 763-785.

Hepworth, K. (2012). Abject citizens: Italian 'Nomad Emergencies' and the deportability of Romanian Roma. Citizenship Studies, 16(3-4), 431-449.

Humphris, R. (2017). On the threshold: Becoming Romanian Roma, everyday racism and residency rights in transition. Social Identities, 24, 1-15. https://doi.org/10.1080/13504630.2017 .1335831 .

Institute for Ethnic Studies. (2004). Spletno mesto za romske svetnike. [online] Available at: http:// www.inv.si/romsvet/dobro_je_vedeti5c7e.html?p=4. Accessed 6 Nov 2017.

Klopčič, V. (2007). Položaj Romov v Sloveniji: Romi in Gadže. Ljubljana: Institute for Ethnic Studies.

Kóczé, A. (2011). Gender, ethnicity and class: Romani women's political activism and social struggles. Unpublished PhD thesis, Budapest: CEU.

Kóczé, A. (2017). Race, migration and neoliberalism: distorted notions of Romani migration in European public discourses. Social Identities, 24, 1-15.

Latham, J. (1999). Roma of the former Yugoslavia. Nationalities Papers, 27(2), 205-226. https:// doi.org/10.1080/009059999109037.

M.R. (2017). Največ Romov živi v Mariboru in Murski Soboti, sledijo Novo mesto, Črnomelj in Kočevje - Moja Dolenjska. [online] Available at: http://moja-dolenjska.si/najvec-romov-ziviv-mariboru-murski-soboti-sledijo-novo-mesto-crnomelj-kocevje/. Accessed 6 Nov 2017.

Magazzini, T., \& Piemontese, S. (2016). 'Roma' migration in the EU: The case of Spain between 'new' and 'old' minorities. Migration Letters, 13(2), 228-241.

Martin, P., Scullion, L., \& Brown, P. (2017). We don't rely on benefits': Challenging mainstream narratives towards Roma migrants in the UK Philip Martin, Lisa Scullion and Philip Brown. Social Policy Review, 29, Policy Press at the University of Bristol, UK, 199-217.

Matras, Y. (2000). Romani migrations in the post-communist era: Their historical and political significance. Cambridge Review of International Affairs, 13(2), 32-50.

Matras, Y., \& Leggio, D. (2018). Open borders, unlocked cultures. Abingdon: Oxon.

McGarry, A. (2017). Romaphobia: The last acceptable form of racism. London: Zed Books.

Nacu, A. (2010). The politics of Roma migration: Framing identity struggles among Romanian and Bulgarian Roma in the Paris region. Journal of Ethnic and Migration Studies, 37(1), 135-150.

Novinšćak, K. (2009). The recruiting and sending of Yugoslav 'Gastarbeiters': Between socialist demands and economic needs. In U. Brunnbauer (Ed.), Transnational societies, transterritorial politics (pp. 121-144). München: Oldenbourg. 
Office for National Minorities. (2005). Romska skupnost | Urad vlade Republike Slovenije za narodnosti. [online] Available at: http://www.un.gov.si/si/manjsine/romska_skupnost/. Accessed 6 Nov 2017.

Pantea, M. (2012). From 'making a living' to 'getting ahead': Roma women's experiences of migration. Journal of Ethnic and Migration Studies, 38(8), 1251-1268.

Parker, O. (2012). Roma and the politics of EU citizenship in France: Everyday security and resistance. JCMS: Journal of Common Market Studies., 50(3), 475-491.

Parker, O., \& Toke, D. (2013). The politics of a multi-level citizenship: French republicanism, Roma mobility and the EU. Global Society, 27(3), 360-378.

Perič, T., \& Demirovski, M. (2000). Unwanted: The exodus of Kosovo Roma (1998-2000). Cambridge Review of International Affairs, 13(2), 83-96.

Pojbič, J. (2014). Pred dnevom Romov odstranili protiromski grafit. [online] Available at: http:// www.delo.si/novice/slovenija/pred-dnevom-romov-odstranili-protiromski-grafit.html. Accessed 6 Nov 2017.

Pomurec.com. (2014). FOTO: Romi iz stavbe nekdanje kirurgije odstranili diskriminatorni grafit Pomurec.com. [online] Available at: http://www.pomurec.com/vsebina/23020/FOTO_Romi_ iz_stavbe_nekdanje_kirurgije_odstranili_diskriminatorni_grafit. Accessed 6 Nov 2017.

Ram, M. (2013). European integration, migration and representation: The case of Roma in France. Ethnopolitics, 13(3), 203-224.

Reporter. (2017). Breznik svari vlado: Gre za usodo 20.000 ljudi, $k i$ delajo $v$ Avstriji. Retrieved from: https://reporter.si/clanek/slovenija/ breznik-svari-vlado-gre-za-usodo-20000-ljudi-ki-delajo-v-avstriji-494198

Richardson, J. (2014). Roma in the news: An examination of media and political discourse and what needs to change. People, Place and Policy Online., 8, 51-64.

Sardelić, J. (2012). Kulturne reprezentacije manjšin: Slovenski Romi Pred osamosvojitvijo in po njej. Unpublished $\mathrm{PhD}$ thesis.

Sardelić, J. (2016). Roma between an ethnic group and an underclass as portrayed through newspaper discourses in socialist Slovenia. In R. Archer, P. Stubbs, \& I. Duda (Eds.), Social inequalities and discontent in Yugoslavia (pp. 95-111). London: Routledge.

Sardelić, J. (2017a). The position and agency of the 'irregularized': Romani migrants as European semi-citizens. Politics, 37, 332-346. p.026339571666853.

Sardelić, J. (2017b). In and out from the European margins: Reshuffling mobilities and legal statuses of Romani minorities between the Post-Yugoslav space and the European Union. Social Identities, 24, 1-16.

Sardelić, J. (2017c). From temporary protection to transit Migration: Responses to refugee crises along the Western Balkan Route. RSCAS 2017/35 Working Paper. [online] Available at: http:// cadmus.eui.eu/handle/1814/47168. Accessed 10 Jan 2019.

Sardelić, J. (2018). Politics around Romani migration: National and European perspectives. In J. Caetano \& S. Croucher (Eds.), Politics of migration. New York: Routledge. (In print.

Sigona, N. (2003). How can a 'Nomad' be a 'Refugee'? Sociology, 37(1), 69-79.

Sobotainfo. (2014). Delavci migranti: “Če poslušnosti ne bo, gremo na ulice v Ljubljano!". (2018). Retrieved from https://sobotainfo.com/novica/politika-gospodarstvo/ delavci-migranti-ce-poslusnosti-ne-bo-gremo-na-ulice-v-ljubljano/101075

Solimene, M. (2011). 'These Romanians have ruined Italy'. Xoraxané Romá, Romanian Roma and Rome. Journal of Modern Italian Studies, 16(5), 637-651.

Szilvasi, M. (2018). Parallel claims for the human right to water: The case of Roma in Slovenia. In D. Archibugi \& A. E. Benli (Eds.), Claiming citizenship rights in Europe: Emerging challenges and political agents. London: Routledge.

UNDP (2015). Decade of Roma inclusion: Progress report. United Nation Development Program, Europe and Central Asia.

van Baar, H. (2017). Contained mobility and the racialization of poverty in Europe: The Roma at the development-security nexus. Social Identities, 24, 1-17. 
Vermeersch, P. (2012). Reframing the Roma: EU initiatives and the politics of reinterpretation. Journal of Ethnic and Migration Studies, 38(8), 1195-1212.

Vermeersch, P. (2013). The plight of Eastern Europe's Roma. In A. Fagan \& P. Kopecký (Eds.), The Routledge handbook of East European politics (pp. 225-236). New York: Routledge.

Vermeersch, P. (2018). The plight of Eastern Europe's Roma. In A. Fagan \& P. Kopecky (Eds.), The routledge handbook of East European politics. New York: Routeldge.

Vlase, I., \& Voicu, M. (2013). Romanian Roma migration: The interplay between structures and agency. Ethnic and Racial Studies, 37(13), 2418-2437.

Vrăbiescu, I., \& Kalir, B. (2017). Care-full failure: How auxiliary assistance to poor Roma migrant women in Spain compounds marginalization. Social Identities, 24, 1-13.

Vullnetari, J. (2012). Beyond 'choice or force': Roma mobility in Albania and the Mixed migration paradigm. Journal of Ethnic And Migration Studies, 38(8), 1305-1321.

Yildız, C., \& De Genova, N. (2017). Un/Free mobility: Roma migrants in the European Union. Social Identities, 24, 1-17.

Yuval-Davis, N., Wemyss, G., \& Cassidy, K. (2017). Introduction to the special issue: Racialized bordering discourses on European Roma. Ethnic and Racial Studies, 40(7), 1047-1057.

Zorn, J. (2009). A case for Slovene nationalism: Initial citizenship rules and the erasure. Nations and Nationalism., 15(2), 280-298.

Open Access This chapter is licensed under the terms of the Creative Commons Attribution 4.0 International License (http://creativecommons.org/licenses/by/4.0/), which permits use, sharing, adaptation, distribution and reproduction in any medium or format, as long as you give appropriate credit to the original author(s) and the source, provide a link to the Creative Commons licence and indicate if changes were made.

The images or other third party material in this chapter are included in the chapter's Creative Commons licence, unless indicated otherwise in a credit line to the material. If material is not included in the chapter's Creative Commons licence and your intended use is not permitted by statutory regulation or exceeds the permitted use, you will need to obtain permission directly from the copyright holder.

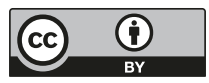

